\title{
Effect of Lakhra Fly Ash as Partial Replacement of Cement in Traditional Concrete
}

\author{
MASROOR ALI JATOI*, GHULAM SHABIR SOLANGI**, FAHAD ALI SHAIKH*, SAROSH*, AND \\ SHABIR*
}

RECEIVED ON 08.03.2017 ACCEPTED ON 30.10.2018

ABSTRACT

\begin{abstract}
This study was aimed to determine the effect of LFA(Lakhra Fly Ash) as partial replacement of cement in concrete. To conduct this study, a total of 72 standard concrete cylinders were cast with 1:2:4 proportions at 0.5 water-binder ratios. Cement was partially replaced by weight with LFA and the percentage replacements of FA(Fly Ash) were kept as 0, 5, 15, 25, 40 and 50\%. In addition to that, workability of each mix was determined by Slump Cone test and Compaction Factor test. Out of 72 cylinders, 36 cylinders were tested to determine the compressive strength while the remaining 36 cylinders were tested to determine the tensile strength of concrete, at 7 days curing period, by using UTM (Universal Testing Machine). The results revealed that $25 \%$ replacement of binder with LFA, determined an increase in compressive strength of concrete up to $15 \%$ as compared to normal cement concrete. Moreover, the tensile strength of concrete also increased up to $16 \%$ for the same percentage replacement. Furthermore, it also increased the workability, cohesiveness and surface finishes of concrete. This finding can help to reduce the admixture dosage or the water content of the mix. On the contrary, the compressive strength as well as the tensile strength of concrete decreased in case of 40 and $50 \%$ replacements of the cement with FA.
\end{abstract}

Key Words: Ordinary Concrete, Fly Ash Concrete, Workability, Compressive Strength, Tensile Strength.

\section{INTRODUCTION}

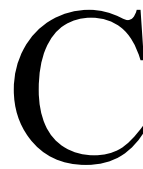

oncrete is a mixture of binding material, fine aggregates, coarse aggregates, and water. It has become an important material for the society's infrastructure. Its versatility, durability, sustainability, and economy have made it the world's

most widely used construction material. One of the major advantages of concrete is that it can be molded into any required shape. That is why it is frequently used for the construction of buildings, bridges and other civil engineering structures.

\footnotetext{
Authors E-Mail: (masroor_eng@hotmail.com,solangi_shabir@yahoo.com, fahad.ali@faculty.muet.edu.pk, saroshrajput1@gmail.com, 13shabbir59@gmail.com)

* Department of Civil Engineering, Mehran University of Engineering \& Technology, Jamshoro, Pakistan.

** Department of Civil Engineering, Mehran University of Engineering \& Technology, Shaheed Zulfiquar Ali Bhutto Campus, Khairpur Mir's, Pakistan.

This is an open access article published by Mehran University Research Journal of Engineering and Technology, Jamshoro under the CC by 4.0 International License.
} 
Concrete plays a vital role in the construction industry; therefore, improvements are continuously being made in properties of this material. The decreasing quantity of raw materials used for manufacturing of cement is a big challenge for the construction industry. Hence, there is dire need to replace cement with alternative materials to overcome the problem of decreasing resources of this component.

FA is a fine residual material obtained from the ignition of coal in power generation plants. It can be used as a partial substitute for cement in concrete. In addition to that, this valorization option can provide an environmental friendly way of its disposal and reuse [1]. It is the most common pozzolana in the world. Furthermore, particles of FA are almost spherical in shape, ranging in diameter varying from 0.5-150 microns. As a result, FA freely blends in the mixture, which makes it a desirable admixture for concrete. It is generally heterogeneous, consisting of a mixture of glassy particles such as quartz, mullet and iron oxide. On the other hand, FA reduces the density of concrete; therefore, it can be used in producing lightweight concrete which may reduce the production cost of concrete. Thus, the use of such by-products as the partial substitution of cement, make the concrete economical. Additionally, it has also environmental and technical benefits. Hence, FA is recommended to be used in the manufacturing of cement and concrete rather than disposed off to spoil the environment [2].

Only a few years ago, FA generated by the burning of coal was considered as a waste material. Later on, its use as a pozzolanic additive to cement has changed the way this residual material is considered.
Apart from that, the industrial wastes are a big problem for the environment. So, it is necessary to make an attempt to use these waste materials in the construction industry to overcome the environmental problems.

LPS (Lakhra Power Station), Sindh, Pakistan, is Pakistan's second-biggest power station based on lignite coal. It has been producing a huge quantity of FA as residual material from its chimney. Lakhra coal reserves are estimated to about 1328 million tons [3]. Sil and Roy [4] conducted a study and concluded that by partial replacement of cement as well as sand with FA, the properties of concrete can be improved. In addition, Sabet, et. al. [5] also reported that mechanical and durability characteristics of the mixes can be improved by using mineral admixtures. Moreover, FA reduces the environmental pollution, so it may be used as a partial replacement of cement in the lightweight concrete mixture. It is possible to produce a lightweight concrete cylinder with a compressive strength of 25 Mpa by the use of FA [6]. It is also observed that with an increase in age, the compressive strength of concrete also increases for FA replaced concrete [7]. The concrete made by using FA had good strength and durability as compared to conventional aggregate in the severe environment [8]. In addition to that, Reddy et. al. [9] reported that replacement of cement with FA up to $20 \%$ significantly improved the compressive strength of concrete mix. The application of FA as partial replacement of cement also improves the durability of concrete [10]. Shahab et. al. [11] determined the effects of FA and bentonite as partial replacement of OPC (Ordinary Portland Cement) in mass concrete. Three types of concrete mixes with varying percent of partial replacement of OPC were investigated. Analysis 
revealed that mass concrete blocks made of $25 \%$ bentonite and 25\% FA resulted in more uniform properties, or in other words, suffered least from large concrete placement by reducing the heat of hydration. Ajwad et. al. [12] assessed the durability of concrete by adding the low-quality FA to concrete and found that addition of low-quality FA with an activator has a positive impact on carbonation and reinforcement corrosion resistance. Akram et. al. [13] investigated the effect of FA and RHA (Rice Husk Ash) as high volume replacement of cement. Mix proportions were prepared for cement replacement of 50 and $70 \%$ by FA, RHA and the combination of these two. Control mix with no FA and RHA was also analyzed. Results indicated that the density and compressive strength of concrete blend were higher than mixes containing only FA and RHA and combination of these two. The study concluded that high volume replacement of cement by FA and RHA is feasible. Memon et. al. [14] analyzed the effect of silica fume on the fresh and hardened properties of FA-based SCGC (SelfCompacting Geopolymer Concrete). The results indicated that the addition of silica fume as a partial replacement of FA resulted in the loss of workability; nevertheless, the mechanical properties of hardened concrete. Memon et. al. [15] investigated the effect of curing conditions on the compressive strength of SCGC prepared by using FA as a base material and the combination of sodium hydroxide and sodium silicate as an alkaline activator. Test results indicated that longer curing time and curing the concrete specimens at higher temperatures resulted in higher compressive strength. Memon et. al. [16] analyzed the strength of concrete cubes (6x6" in cross-section) made with OPC and with different configurations of FA by replacing cement and fine aggregate. The study concluded that compressive strength of concrete cubes made by replacing $100 \%$ fine aggregate by FA was higher than the concrete cubes made with OPC at all 3, 7 and 28 days curing ages. On the other hand, the compressive strength of concrete cubes made by replacing 10 and $25 \%$ cement by FA was slightly lower than the concrete cubes made with OPC at all curing periods, whereas, the compressive strength of concrete cubes made by replacing 50 and $75 \%$ of cement by FA was quite lower than the concrete cubes made with OPC at all curing ages. Tahir and Moeen [17] evaluated the effect of the chemical composition of FA alone on the strength of concrete. It was found that contribution of chemical composition to concrete strength increased with age and with an increase in FA-binder ratio and it ranged from $12-46 \%$ of total strength.

The properties of FA vary from source to source, moreover, the percentage contents of FA in the present study are different than those of previous studies carried out in Pakistan. The literature also reveals that the tensile strength of concrete made with partial replacement of LFA is still undetermined. Hence, the present study was conducted to assess the suitability of using LFA as a partial replacement of cement in ordinary concrete.

\section{MATERIALS AND METHODOLOGY}

For this study, a total number of 72 standard cylinders having dimensions of $150 \mathrm{~mm}$ (6 inches) diameter and $300 \mathrm{~mm}$ (12 inches) a total depth were cast with 1:2:4 proportion at 0.5 water-binder ratios. Of the 72 cylinders, 36 cylinders were tested to determine the compressive strength and the rest of 36 cylinders were tested for

Mehran University Research Journal of Engineering \& Technology, Volume 38, No. 4, October, 2019 [p-ISSN: 0254-7821, e-ISSN: 2413-7219] 
tensile strength at 7 days curing period. Cement was partially replaced with FA at different percentages of 0 , $5,15,25,40$ and $50 \%$. Workability of each mix was determined by Slump Cone test and Compaction Factor test. The Compressive and Tensile strength was determined by UTM. The methodology adopted in the present study is described in the form of flow chart as shown in Fig. 1.

For the present study, OPC manufactured by Falcon Cement Factory was used. The consistency test, initial and final setting time test and fineness tests were performed in the Concrete Laboratory, Department of Civil Engineering, Mehran University of Engineering \& Technology, Jamshoro, Pakistan. The initial and final setting time of cement was determined as 50 minutes and 12 hours respectively and percentage of fineness was found as $91.4 \%$.

Coarse aggregates used were carried out from the very famous quarry of coarse aggregate at Nooriabad. Crushed stone having a maximum aggregate size of $40 \mathrm{~mm}$ were used. Basic properties of coarse aggregates such as specific gravity, weight density, water absorption and gradation (sieve analysis) were worked out according to the ASTM C136-01 and ASTM C136-14. The specific gravity and water absorption of coarse aggregates were found as 2.55 and $1.967 \%$, respectively.

Particle size distribution of coarse aggregate was determined by sieve analysis using mechanical sieve shaker. Oven dried samples were used for this test and the results of sieve analysis are described in Fig. 2.

Fine aggregates were collected from the very famous quarry of Sindh named Bolari. Fine aggregates passing $60 \%$ from 600 -micron sieve were used. According to ASTM C 128-01 standards, fine aggregates were tested for the following properties namely specific gravity, weight density, water absorption and fineness modulus. The specific gravity of fine aggregate was determined using $500 \mathrm{ml}$ of water in the bottle and it was found as 2.61.

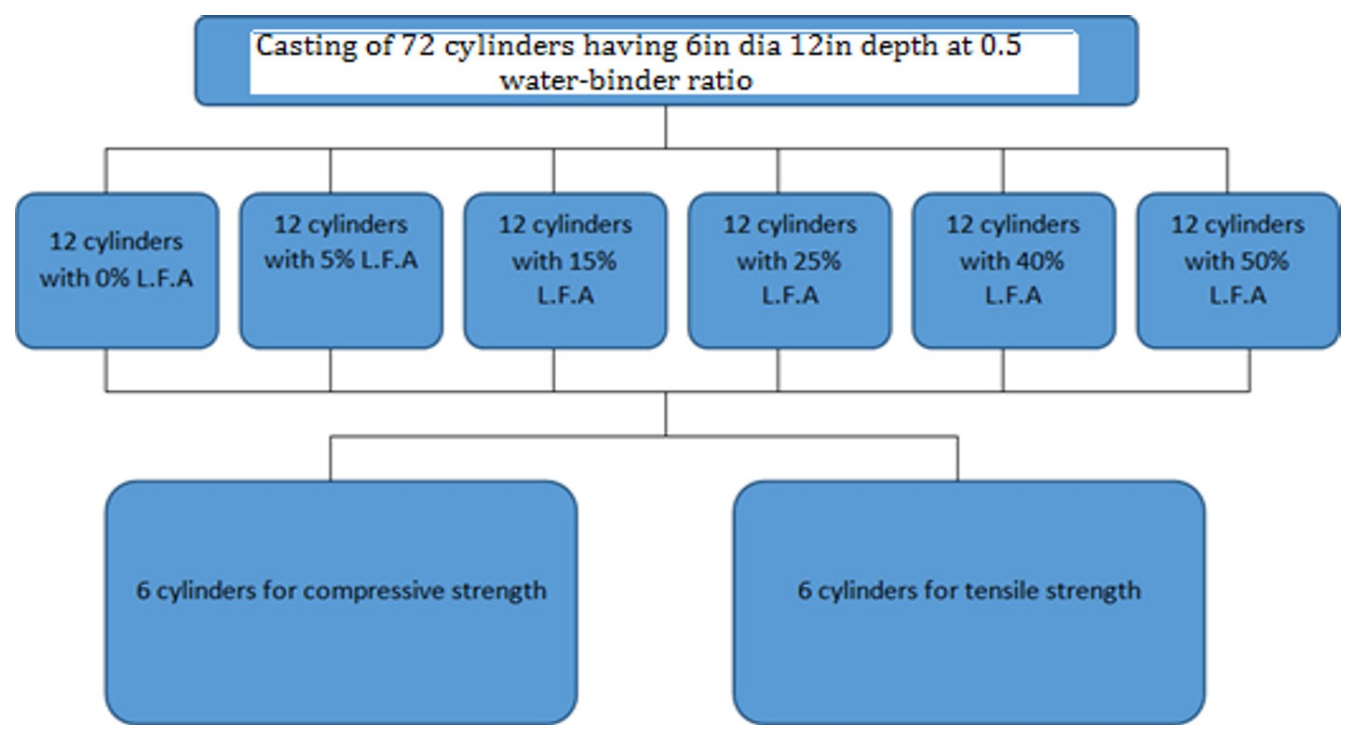

FIG. 1. FLOW CHART-METHODOLOGY

Mehran University Research Journal of Engineering \& Technology, Volume 38, No. 4, October, 2019 [p-ISSN: 0254-7821, e-ISSN: 2413-7219] 1048 
Particle size distribution was determined by sieve analysis using mechanical sieve shaker and the ovendried sample was used. Fineness modulus was 276/100 $=2.76$. The graphical representation of percent of particles passage function on sieve size is given in Fig. 3.
Water free of oil, acid and alkali, salts and organic material was used for mixing the ingredients and curing. FA collected from LPP (Lakhra Power Plant) was used as a partial alternative to cement in concrete. Materials used in the present study such as coarse aggregates and LFA are shown in Figs. 4-5.

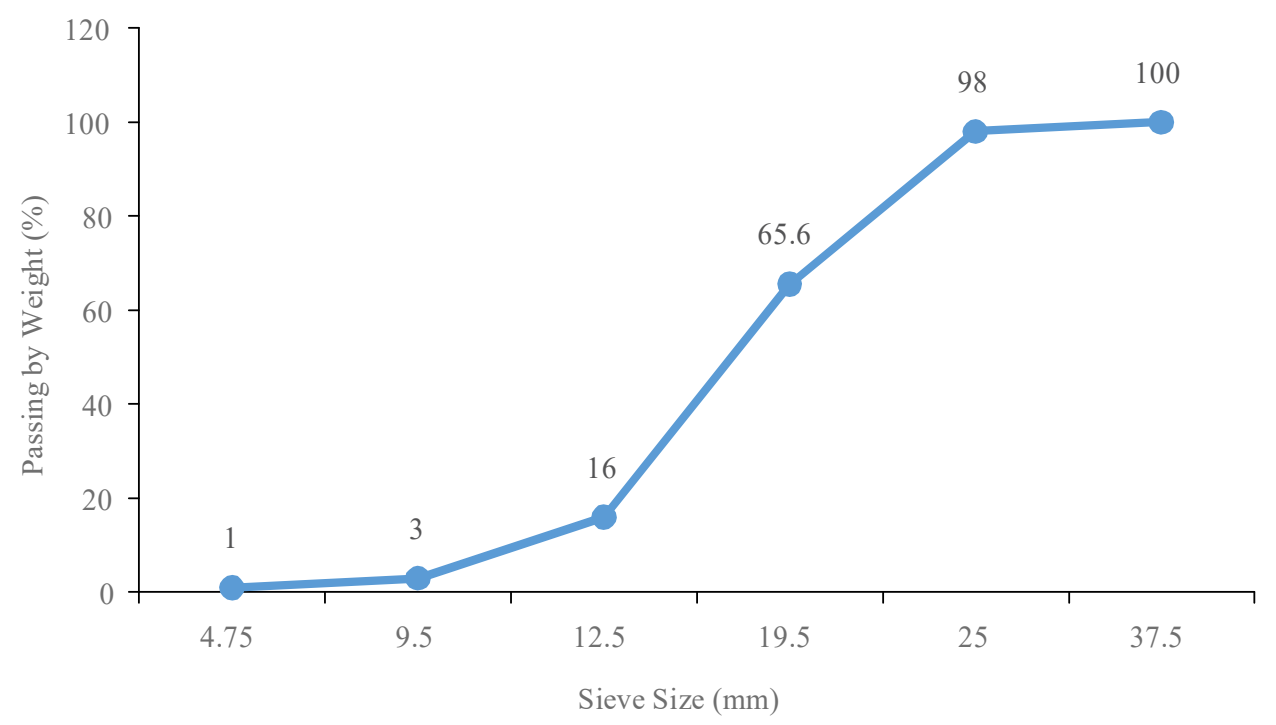

FIG. 2. PARTICLE SIZE DISTRIBUTION OF COARSE AGGREGATE

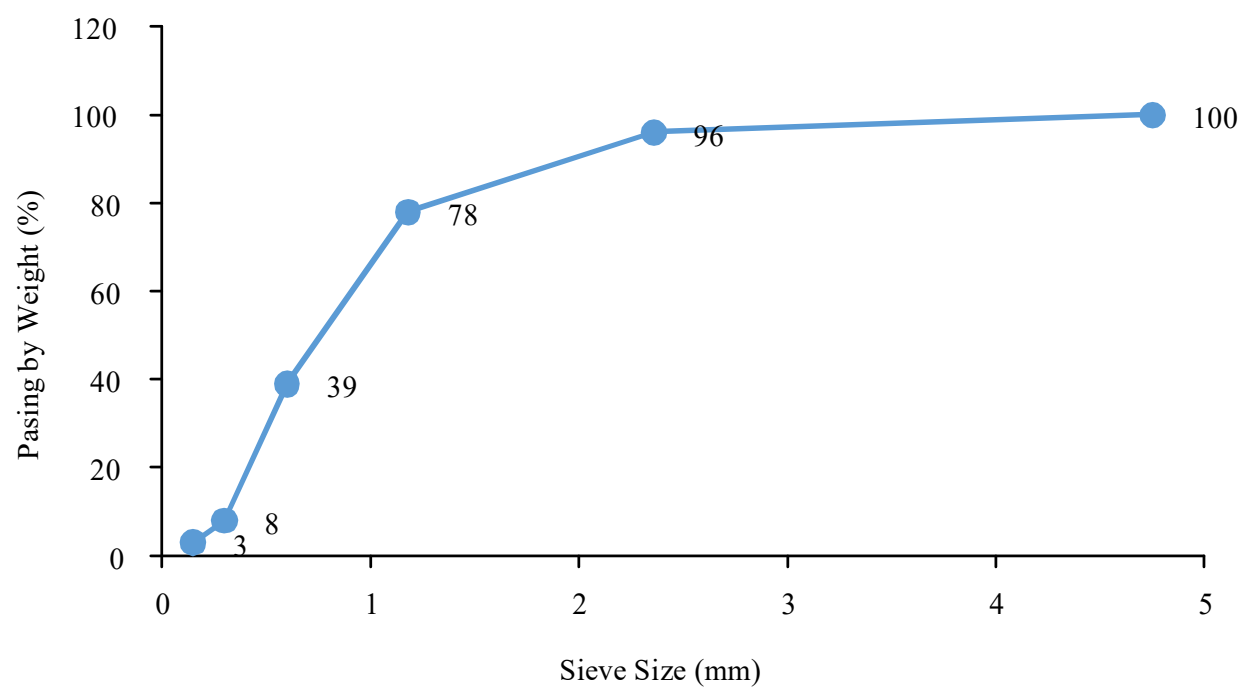

FIG. 3. PARTICLE SIZE DISTRIBUTION OF FINE AGGREGATE 


\subsection{Calculation of Quantities for Design Mix Proportions}

With the ratio 1:2:4, quantities of cement, fine aggregate and coarse aggregate were worked out. Each mix had 12

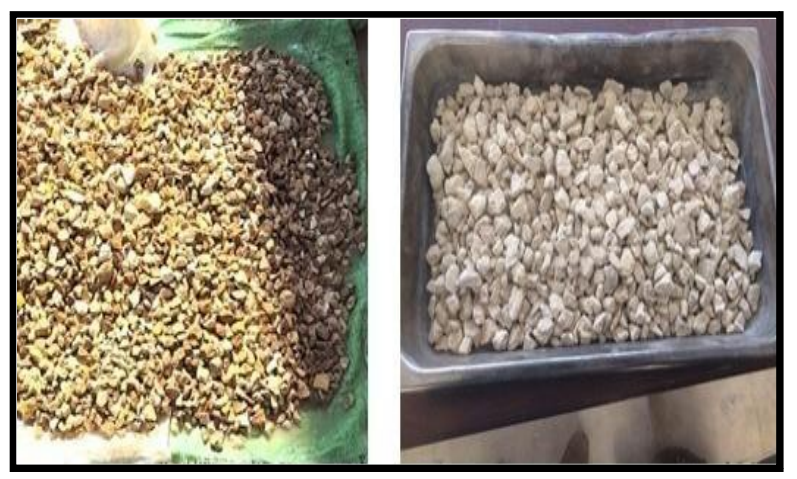

FIG. 4. COARSE AGGREGATES

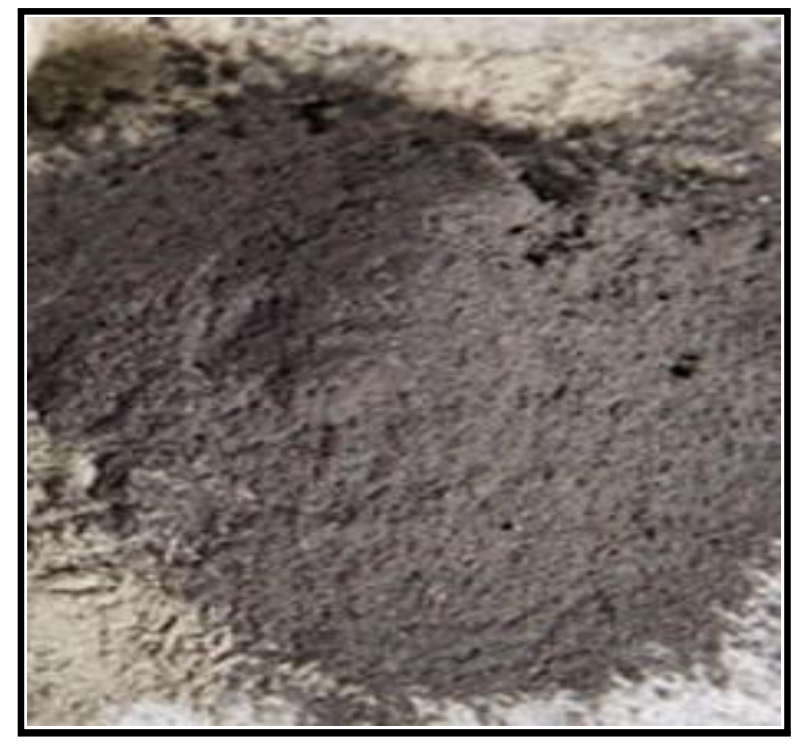

FIG. 5. LAKHRA FLY ASH cylinders prepared, for different Lakhra FA content. Calculations for each mix are given below:

Volume of a cylinder: $0.235 \mathrm{cft}$

Weight of a cylinder $=$ density $\times$ volume $=144 \times 0.235=$ $33.9 \mathrm{lbs}=15.1 \mathrm{~kg}$

Concrete ratio: $1: 2: 4$

Total parts $=1+2+4=7$

Weight of cement $=15.1 / 7=2.157 \mathrm{kgs}$

Weight of fine aggregate $=2 \times 2.157=4.314 \mathrm{kgs}$

Weight of coarse aggregate $=4 \times 2.157=8.628 \mathrm{kgs}$

Quantities required for each mix are established (each mix having 12 cylinders) as shown in Table 1.

The replacement percentages of FA for Mix 1, 2, 3, 4, 5 and 6 , were used as $0,5,15,25,40$ and $50 \%$ respectively.

Workability of plastic concrete used for the present study was determined using Slump cone as well as by Compaction Factor test and it was concluded that use of FA can increase the workability of concrete.

After casting, the cylinders (Fig. 6) were cured for seven days with clean and potable water at room temperature

TABLE 1. MIX DESIGN PROPORTIONS

\begin{tabular}{|c|c|c|c|c|c|c|}
\hline Material & $\begin{array}{c}\text { Mix-1 } \\
(\mathrm{kg})\end{array}$ & $\begin{array}{c}\text { Mix-2 } \\
(\mathrm{kg})\end{array}$ & $\begin{array}{c}\text { Mix-3 } \\
(\mathrm{kg})\end{array}$ & $\begin{array}{c}\text { Mix-4 } \\
(\mathrm{kg})\end{array}$ & $\begin{array}{c}\text { Mix-5 } \\
(\mathrm{kg})\end{array}$ & $\begin{array}{c}\text { Mix-6 } \\
(\mathrm{kg})\end{array}$ \\
\hline Cement & 25.88 & 24.58 & 22 & 19.41 & 15.53 & 12.94 \\
\hline Fly Ash & 0 & 1.30 & 3.88 & 6.47 & 10.35 & 12.94 \\
\hline Fine Aggregate & 51.77 & 51.77 & 51.77 & 51.77 & 51.77 & 51.77 \\
\hline Coarse Aggregate & 103.54 & 103.54 & 103.54 & 103.54 & 103.54 & 103.54 \\
\hline w/c Ratio & 0.5 & 0.5 & 0.5 & 0.5 & 0.5 & 0.5 \\
\hline
\end{tabular}

Mehran University Research Journal of Engineering \& Technology, Volume 38, No. 4, October, 2019 [p-ISSN: 0254-7821, e-ISSN: 2413-7219] 1050 
in water tank available in the Concrete Laboratory, Mehran University of Engineering \& Technology, Jamshoro, Pakistan. Then compressive and tensile strengths were determined using UTM (Figs. 7-8).

\section{RESULTS AND DISCUSSION}

In this section, the results obtained from the experiments are analyzed in order to assess the influence of LFA replacing cement in concrete preparation, in relation to the normal concrete.

A total of 72 cylinders with standard dimensions were cast, 6 mixes with different percentages of LFA of $0,5,15$, 25,40 and $50 \%$ of cement were prepared. For each mix, 12 cylinders were cast. Of the total 12 cylinders corresponding to a defined mixture, 6 were tested for compressive strength and 6 were tested for tensile strength.

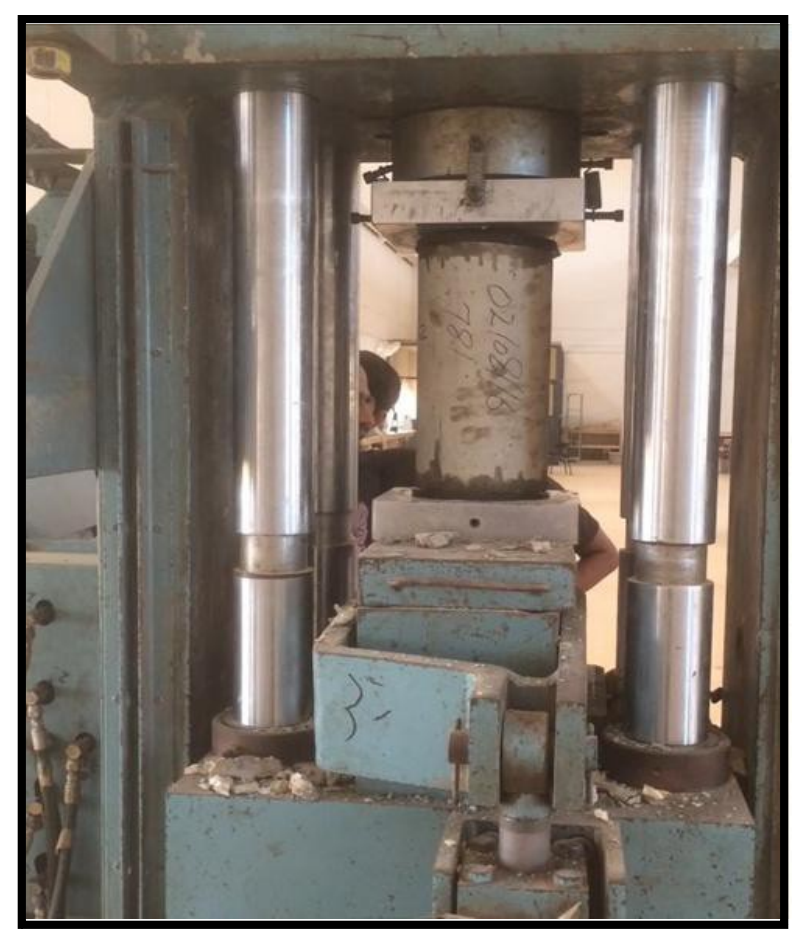

FIG. 6. CONCRETE IN CYLINDERS

\subsection{Slump Test}

Fig. 9 shows the loss of slump at different percentage replacements of cement with LFA.

Fig. 9 clearly depict that the slump loss of normal cement concrete is less than that of concrete in which cement is partially replaced with LFA. The results also show that as

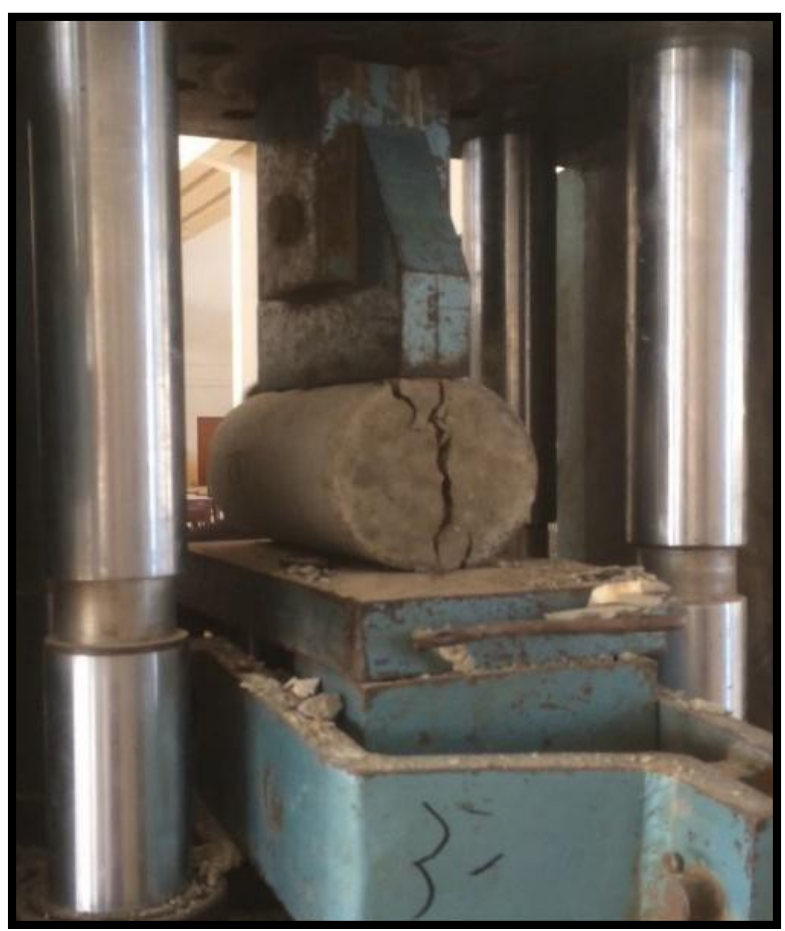

FIG. 7. COMPRESSIVE STRENGTH TEST SETUP

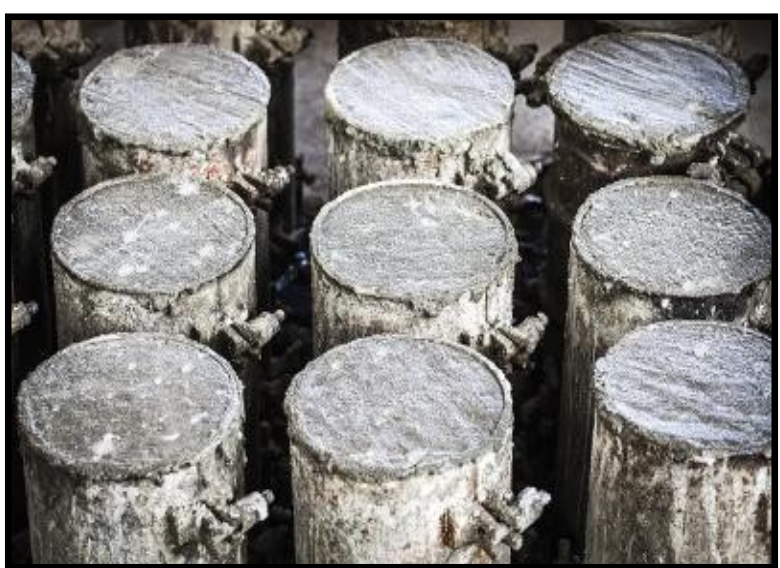

FIG. 8. TENSILE STRENGTH TEST SETUP

Mehran University Research Journal of Engineering \& Technology, Volume 38, No. 4, October, 2019 [p-ISSN: 0254-7821, e-ISSN: 2413-7219] 
the percentage of LFA increases, the slump loss also increases. The slump loss of concrete containing 50\% LFA is increased up to $41 \%$ as compared to normal cement concrete. Furthermore, Slump loss of concrete having $40 \%$ LFA increased up to $34 \%$ as compared to normal concrete and the slump loss of concrete containing 25, 15 and 5\% LFA increased up to 29,20 , and $14 \%$ respectively as compared to normal cement concrete.

\subsection{Compacting Factor Test}

Compacting factor indicates the degree of compactness. As the percentage of LFA increases, the consistency of the mix also increases.
The compacting factor values for different percentages of LFA are given in Fig. 10.

Fig. 10 shows that the compacting factor of normal cement concrete is less than that of concrete in which cement is partially replaced with LFA. The results show that as the percentage of LFA increases, the compacting factor also increases. The compacting factor of concrete containing $50 \%$ LFA is increased up to $3.5 \%$ as compared to normal cement concrete. Moreover, compacting factor of concrete having $40 \%$ LFA increased up to $2.6 \%$ as compared to normal concrete and the compacting factor of concrete containing 25, 15 and 5\% LFA increased up to 2.4, 1.3, and $0.6 \%$ respectively as compared to normal cement concrete.

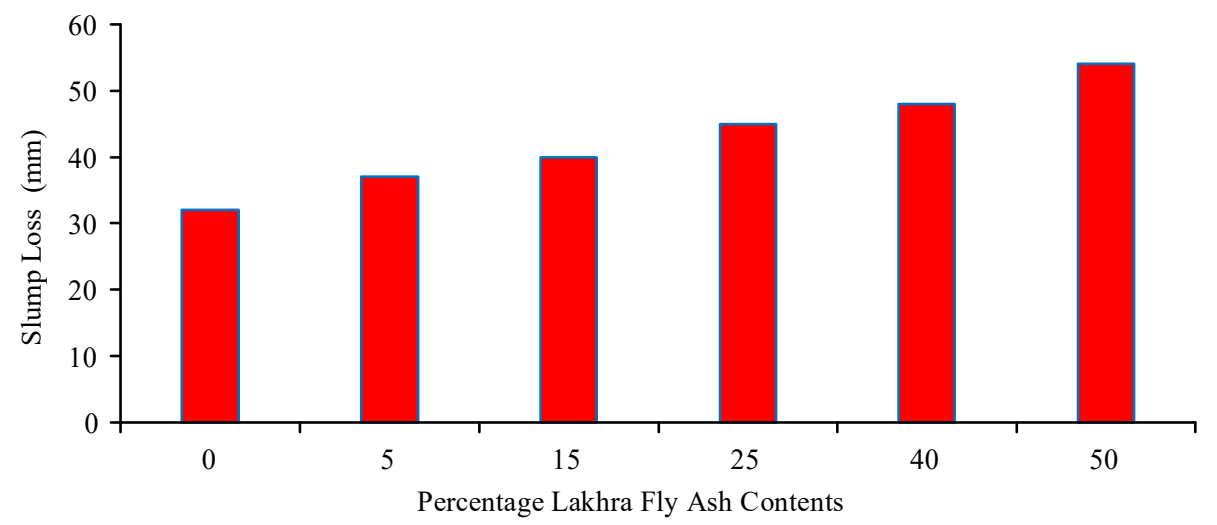

FIG. 9. SLUMP WITH DIFFERENT CONTENTS OF LAKHRA FLY ASH

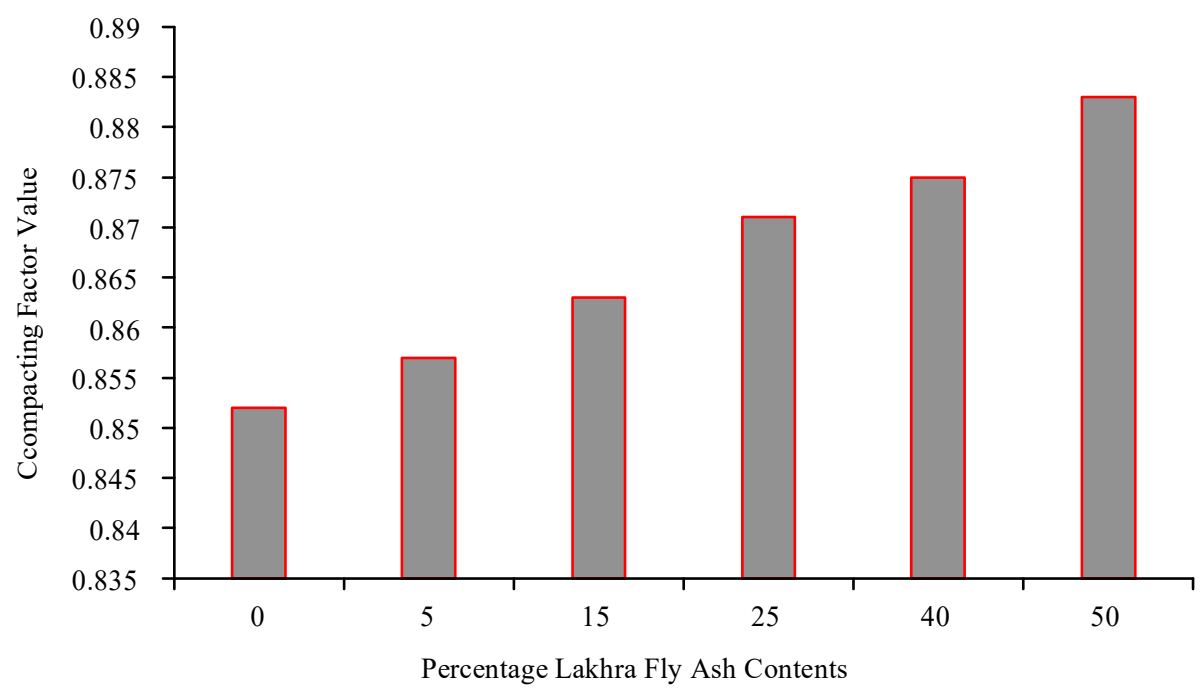

FIG. 10. COMPACTING FACTORS WITH DIFFERENT LAKHRA FLY ASH VALUE

Mehran University Research Journal of Engineering \& Technology, Volume 38, No. 4, October, 2019 [p-ISSN: 0254-7821, e-ISSN: 2413-7219] 1052 


\subsection{Compressive Strength}

The compressive strength test was performed and the compressive strength of normal concrete and the concrete made with different percentage replacements of cement were compared. Table 2 and Fig. 11 show the change in the compressive strength of concrete with a change in the percentage of LFA.

At seven days of curing time, concrete usually gains about $60-75 \%$ of the 28 days strength, hence in the present study, the compressive and tensile strength of concrete after 7 days curing with 5, 15 and $25 \%$ replacement of cement with LFA was analyzed. The analysis revealed that compressive strength of concrete after 7 days curing with 5, 15 and $25 \%$ replacement of cement with LFA increased up to 2,9 and $15 \%$ respectively as compared to normal concrete. However, the compressive strength of concrete with 40 and $50 \%$ replacement decreased by 9 and $15 \%$ respectively as compared to normal concrete.

\subsection{Tensile Strength}

The tensile strength test on concrete cylinders was performed. The tensile strength of normal concrete and the concrete made with different percentages of LFA were obtained (Table 3 and Fig. 12). Concrete cylinders were placed in the UTM and the load at failure was observed and recorded. The tensile strength was determined by using the Equation (1).

$$
\mathrm{T}=\frac{2 \mathrm{P}}{\pi \mathrm{dl}}
$$

The tensile strength of concrete after 7 days curing with 5,15 and $25 \%$ replacement of cement with LFA increased up to 7,11 and $16 \%$ respectively as compared to normal concrete. However, the tensile strength of concrete with 40 and $50 \%$ replacements decreased by 11 and 20\% respectively as compared to normal concrete.

TABLE 2. COMPRESSIVE STRENGTH AT DIFFERENT LAKHRA FLY ASH CONTENTS

\begin{tabular}{|c|c|}
\hline Mix & Compressive Strength (Mpa) \\
\hline $\mathrm{M}_{0}$ & 14.26 \\
\hline $\mathrm{M}_{5}$ & 14.53 \\
\hline $\mathrm{M}_{15}$ & 15.6 \\
\hline $\mathrm{M}_{25}$ & 16.5 \\
\hline $\mathrm{M}_{40}$ & 13.09 \\
\hline $\mathrm{M}_{50}$ & 12.14 \\
\hline
\end{tabular}

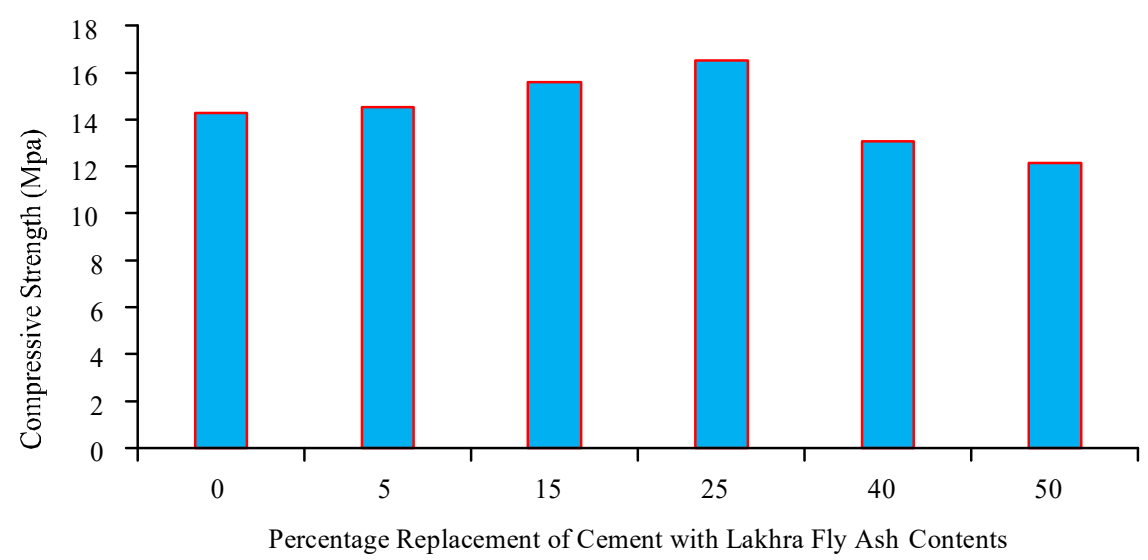

FIG. 11. COMPRESSIVE STRENGTH OF CONCRETE AT DIFFERENT REPLACEMENT \%AGES OF CEMENT WITH LAKHRA FLY ASH CONTENTS 
TABLE 3. TENSILE STRENGTH AT DIFFERENT LAKHRA FLY ASH CONTENTS

\begin{tabular}{|c|c|}
\hline Mix & $\begin{array}{c}\text { Compressive Strength } \\
\text { (Mpa) }\end{array}$ \\
\hline $\mathrm{M}_{0}$ & 1.682 \\
\hline $\mathrm{M}_{5}$ & 1.8 \\
\hline $\mathrm{M}_{15}$ & 1.88 \\
\hline $\mathrm{M}_{25}$ & 1.984 \\
\hline $\mathrm{M}_{40}$ & 1.49 \\
\hline $\mathrm{M}_{50}$ & 1.35 \\
\hline
\end{tabular}

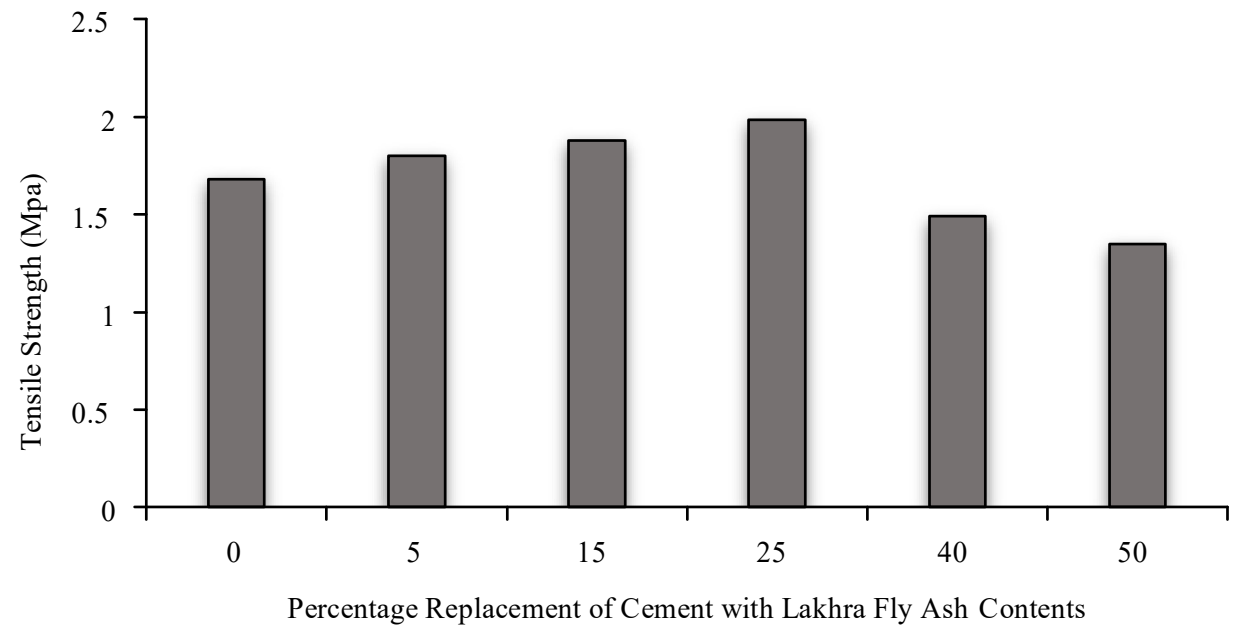

FIG. 12. TENSILE STRENGTH OF CONCRETE AT DIFFERENT REPLACEMENT \%AGES OF CEMENT WITH LAKHRA FLY ASH CONTENTS

\section{CONCLUSION}

Partial replacement of cement with LFA in concrete increased consistency (workability), cohesiveness and surface finishes of concrete. The test results indicated that there is a direct relationship between the percentage of FA and workability. So, the workability of concrete can be improved by using FA. This can help to reduce the admixture dosage or the unit water content of the mix.

Moreover, the results showed that the addition of $25 \%$ of LFA significantly increased the compressive strength of concrete up to $15 \%$ at 7 days curing period at 0.5 waterbinder ratios, as compared to normal cement concrete. However, the compressive strength of concrete with 40 and $50 \%$ replacement decreased by 9 and $15 \%$ respectively as compared to normal concrete.
Likewise, the tensile strength of concrete after 7 days curing with 5, 15 and $25 \%$ replacement of cement with LFA increased up to 7,11 , and $16 \%$ respectively as compared to normal concrete. However, the tensile strength of concrete with 40 and $50 \%$ replacement decreased by 11 and $20 \%$ respectively as compared to normal concrete.

\section{SUGGESTIONS}

It is suggested that for higher percentage replacements of cement with LFA as in concrete (for instance 40 and $50 \%$ ), the curing period of concrete can further be extended to evaluate the properties of concrete in the hardened state. 
On the basis of this study, it can be suggested that the durability of composite materials made by the application of FA as partial replacement of cement may be further increased by adding the necessary admixtures in higher percentages at higher curing periods. The use of FA in concrete by replacing cement to some extent will possibly reduce the cost of concrete.

FA can be used in making concrete economical, strong, durable, and environment friendly. Additionally, it also reduces the heat of hydration, therefore, it is also suggested that higher percentages of FA can be used in mass concreting.

\section{ACKNOWLEDGEMENT}

Authors are highly grateful to the technical staff of the Concrete Laboratory, Department of Civil Engineering, Mehran University of Engineering \& Technology, Jamshoro, Pakistan, for providing research facilities regarding this study.

\section{REFERENCES}

Pati, S.L., Kale, J.N., and Suman, S., "Fly Ash Concrete: A Technical Analysis for Compressive Strength”, International Journal of Advanced Engineering Research and Studies, Volume 2, No. 1, pp. 128-129, 2012.

Bremseth, "Fly Ash in Concrete, A Literature Study of the Advantages and Disadvantages", COIN Project Report 18, 2010.

Aziz, S., Pathan, M.I., and Soomro, S.A., "Erosion Problems in Fluidized Bed CombustionPower Plant Based on Lakhra Coal", Journal of Applied Science, Volume 1, No. 3, pp. 145-151, 2006.

Sil, A., and Roy, D.K.S., "Performance of High Volume FlyAsh Concrete Using Local Power Plant Fly Ash”, International Journal ofComposite and Constituent Materials Journals, Volume 1, No. 1, pp. 1-8, 2016.
[5] Sabet, F.A., Nicolas, A., Libre, N.A., and Shekarchi, M.,"Mechanical and Durability Properties of SelfConsolidatingHigh-Performance Concrete Incorporating Natural Zeolite, Silica Fume and Fly Ash”, Earth Reviews, [ISSN: 0950-0618], Elsevier, 2013,

[6] Yasar, E., Atis, C.D., Kilic, A., and Gulsen, H., "Strength Properties of Lightweight Concrete Made with Basaltic Pumice and Fly Ash", Construction Materials, Elsevier, 2003.

[7] Bansal, R., Singh, V., and Pareek, R.K., "Effect on Compressive Strength with Partial Replacement of Fly Ash", International Journal on Emerging Technologies, Volume 6, No. 1, pp. 1-6, 2015.

[8] Swaroop, A.H.L, Venkateswararao, K., and Kondandaramarao, P., "Durability Studies on Concrete with Fly Ash \& Ggbs", International Journal of Engineering Research and Applications, Volume 3, No. 4, pp. 285-289, 2013.

[9] Reddy, S.A.K., and Reddy, K.C., "Effect of Fly Ash on Strength and Durability Parameters of Concrete", International Journal of Science and Research, Volume 4, No. 5, pp. 1368-1370, [ISSN (Online): 2319-7064], 2013 ,

[10] Nath, P., and Sarkar, P., "Effect of Fly Ash on the Durability Properties of HighStrength Concrete", Proceedings of 12th East Asia-Pacific Conference on Structural Engineering and Construction, Australia, 2011.

[11] Shabab, M.E., Shahzada, K., Gencturk, B., Ashraf, M., and Fahad, M., "Synergistic Effect of Fly Ash and Bentonite as Partial Replacement of Cement in Mass Concrete", KSCE Journal of Civil Engineering, Volume 20, No. 5, pp. 1987-1995, 2016.

[12] Ajwad, A., Ilyas, U., Ibne Shafiq, M., Abbas, A., Khan, M.A., and Ali, T., "Assessing Durability of Concrete with Addition of Low-Quality Fly Ash", Proceedings of 2nd International Multi-Disciplinary Conference, Gujrat, Pakistan, 19-20 December 2016.

[13] Akram, T., Memon, S.A., and Akram, R., "Utilization of Fly Ash and Rice Husk Ash as High Volume Replacement of Cement", https://www.researchgate.net/ publication/270885374 
[14] Memon, F.A., Nuruddin, M.F., and Shafiq, N., "Effect of Silica Fume on the Fresh and Hardened Properties of Fly Ash-Based Self-Compacting Geopolymer Concrete", International Journal of Minerals, Metallurgy and Materials, Volume 20, No. 2, 2013.

[15] Memon, F.A., Nuruddin, M.F., Demie S., and Shafiq, N., "Effect of Curing Conditions on Strength of Fly AshBased Self-Compacting Geopolymer Concrete", World Academy of Science, Engineering and Technology International Journal of Civil, Environmental, Structural, Construction and Architectural Engineering Volume 5, No. 8, pp. 342-345, 2011.
[16] Memon, F.A., Memon, N.A., and Memon, R.A., "Study of Compressive Strength of Concrete with Coal Power Plant Fly Ash as Partial Replacement of Cement and Fine Aggregate", Mehran University Research Journal of Engineering and Technology, Volume 29, No. 4, pp. 647-652, Jamshoro, Pakistan, October, 2010.

[17] Tahir, M.A., and Moeen, E.B., "Strength Development of Concrete Due to Chemical Composition of Incorporated Fly Ash", 30th Conference on Our World in Concrete and Structures, Singapore, 23-24 August, 2005 . 